\title{
ÉTICA, DIREITOS FUNDAMENTAIS E OBEDIÊNCIA À CONSTITUIÇÃO
}

\author{
Thadeu Weber*
}

RESUMO - Um Estado democrático de Direito fundamenta suas bases em princípios de justiça universalizáveis. Aplicados a uma Constituição, objetivam-se nos direitos e liberdades fundamentais dos cidadãos. O dever de obedecer a leis injustas, a desobediência civil e a objeção de consciência pressupõem senso de justiça e uma concepção do bem, capacidades morais de uma "pessoa ética".

PALAVRAS-CHAVE - Direitos fundamentais. Justiça. Constituição. Desobediência civil.
ABSTRACT - A democratic State of law puts its bases on principles of justice capable of universal validity. Applied to a constitution, such principles are objectivied in the fundamental rights and liberties of the citizens. The duty of obeying unjust laws, civil disobedience and consciousness objection presuppose a sense of justice and a conception of the good, that is, moral capacities of an "ethical person".

KEY WORDS - Fundamental rights. Justice. Constitution. Civil desobedience.

O Tribunal de última instância não é o Judiciário, nem o Executivo, nem o Legislativo, mas sim o eleitorado como um todo (J. Rawls).

\section{Colocação do problema: \\ Princípios éticos, direitos e liberdades fundamentais}

O grande tema sempre retomado pelos estudiosos da ética refere-se ao problema da fundamentação de seus princípios. Inúmeras questões são objeto de discussão: Existem princípios éticos universalíssimos, que deveriam orientar as estruturas jurídicas e sociais? Como formulá-los e fundamentá-los? São empíricos ou são puramente racionais? São conquistas da história? Têm sua base no "espírito de um povo"? São de ordem divina?

O fato é que precisamos de princípios orientadores e reguladores para as instituições, sobretudo para uma Constituição. Regras normativas precisam ser justificadas, caso contrário, ficam arbitrárias. Leis fundamentam-se em princípios que, por sua vez, devem incluir ou contemplar os direitos e liberdades fundamentais. Têm, portanto, uma dimensão ética. Ou seja, quando falamos da justificação de leis, re-

* Professor da PUCRS.

\begin{tabular}{|l|l|l|l|l|l|}
\hline VERITAS & Porto Alegre & v. 51 & n. 1 & Março 2006 & p. 96-111 \\
\hline
\end{tabular}


portamo-nos a princípios e, quando fundamentamos princípios, estabelecemos valores e, quando falamos de valores, que na sua aplicação requerem regularidade e coerência, tratamos de questões éticas.

A busca de princípios últimos de moralidade é objeto de estudo recorrente na história do pensamento político. É o tema central de Kant, na Fundamentação da Metafísica dos Costumes e na Crítica da Razão Prática. Do conhecimento moral popular parte para a determinação do princípio supremo de moralidade: o imperativo categórico. Sua formulação e origem é puramente racional e, portanto, não pode ser buscada na experiência. Um princípio ético não diz o que é mas enuncia o que deve ser. Hegel considera o "espírito do povo" como ponto de partida para a fundamentação ética de uma Constituição e delega ao "Tribunal da História" a missão do julgamento dos Estados, a partir do seu desenvolvimento. J. Rawls enuncia dois princípios ético-políticos de justiça ${ }^{1}$ como resultado de um acordo das partes na "posição original". ${ }^{2}$ No que se refere ao primeiro princípio, apresenta uma lista de liberdades básicas iguais para todas as pessoas capazes de desenvolver um senso de justiça e ter uma concepção do bem (pessoas éticas). É desse autor e dessa lista e de suas aplicações e garantias que o presente estudo se ocupa de modo especial.

Três aspectos merecem uma atenção inicial:

O primeiro diz respeito a uma melhor especificação das liberdades básicas, anúncio feito através do primeiro princípio de justiça. O referido autor apresenta uma lista de liberdades fundamentais iguais: a liberdade política (o direito de votar e ocupar um cargo público) e a liberdade de expressão e reunião; a liberdade de consciência e de pensamento; as liberdades da pessoa, que incluem a proteção contra a opressão psicológica e a agressão física (integridade da pessoa); o direito à propriedade privada e à proteção contra a prisão e a detenção arbitrárias; os direitos e liberdades abarcados pelo estado de direito (cf. Uma Teoria da Justiça, doravante T. J., p. 65).

O segundo aspecto refere-se à origem dessa lista. De duas maneiras ela pode ser elaborada: uma é histórica e outra é analítica. Do ponto de vista histórico, basta examinar os regimes democráticos mais bem-sucedidos para constatar que os direitos e liberdades, que são realmente básicos, estão aí protegidos. Do ponto de vista analítico, basta avaliar quais liberdades "fornecem as condições políticas e sociais essenciais para o adequado desenvolvimento e pleno exercício das duas faculdades morais das pessoas livres e iguais", que são o senso de justiça e a concepção do bem, e chegaremos àquela lista de liberdades básicas mencionadas, ou seja, logo

1 Podemos encontrar várias formulações dos princípios da justiça, com pequenas revisões e modificações no desdobramento de suas obras. A título de exemplo podemos citar uma delas: (1^) Cada pessoa deve ter o direito igual ao mais abrangente sistema total de liberdades básicas iguais que seja compatível com um sistema semelhante de liberdade para todos. (2ํ) As desigualdades econômicas e sociais devem ser ordenadas de tal modo que, ao mesmo tempo: (a) tragam o maior benefício possível para os menos favorecidos, obedecendo às restrições do princípio da poupança justa, e (b) sejam vinculadas a cargos e posições abertos a todos em condições de igualdade eqüitativa de oportunidades (T. J. p. 333). Em O Liberalismo Político o autor insiste na concepção política de justiça. Conseqüentemente, a formulação dos princípios de justiça sofre alterações (cf. p. 47).

2 A posição original é descrita como sendo uma situação hipotética em que as partes, sob um "véu da ignorância”, visam a formação de um consenso em torno dos princípios de justiça e para tal ignoram seus interesses particulares. 
veremos que essas liberdades são essenciais para que a pessoa se realize como pessoa ética (Justiça como eqüidade: uma reformulação, p. 64). As partes, na "posição original", chegarão a um consenso em torno delas.

O terceiro aspecto diz respeito à aplicação dessas liberdades. Segundo Rawls, o primeiro princípio, que trata dessas liberdades, aplica-se mais especificamente à Constituição (escrita ou não), isto é, as liberdades fundamentais iguais devem ser garantidas pela Constituição.

Rawls reconhece certas lacunas na interpretação dos direitos e liberdades fundamentais e sua prioridade. ${ }^{3}$ Entre elas (crítica de Hart), está o fato de não haver um "critério satisfatório na maneira pela qual as liberdades fundamentais devem ser especificadas e ajustadas umas às outras" (O Liberalismo Político, doravante, L.P., p. 344). Como solucionar ou administrar os possíveis conflitos originários do exercício efetivo dessas liberdades? Qual é o critério adotado para dizer que uma liberdade é mais importante do que outra ou para designar um conjunto de liberdades como realmente essenciais?

Rawls reconhece que os critérios adotados em Teoria são insuficientes. Revisões feitas dão conta de que ao estabelecer liberdades básicas e fixar sua prioridade, se querem garantir, de forma igual, para todos os cidadãos, "as condições sociais essenciais para o desenvolvimento adequado e o exercício pleno e informado de suas duas faculdades morais", que são a capacidade de ter senso de justiça e a capacidade de ter uma concepção do bem (Justiça como eqüidade: uma reformulação, p. 158). O senso de justiça diz respeito à aplicação dos princípios da justiça às instituições sociais. As liberdades políticas e a liberdade de pensamento são essenciais para isso. A capacidade de ter uma concepção do bem diz respeito ao "exercício das faculdades da razão dos cidadãos na formulação, revisão e busca racional de tal concepção ao longo de toda a vida” (idem, p. 159). A liberdade de consciência e a liberdade de associação são fundamentais para isso. As outras liberdades básicas, também essenciais, como a liberdade e a integridade da pessoa e os direitos e liberdades garantidas pelo estado de direito, são necessárias para que outras liberdades essenciais sejam garantidas. Portanto, o critério de importância de uma determinada liberdade básica ou de um conjunto de liberdades básicas, agora é claro: "uma determinada liberdade é mais ou menos importante segundo seja mais ou menos essencialmente implicada no exercício pleno e informado das faculdades morais", o senso de justiça e a concepção do bem (idem, p. 159). Ou seja, segundo o referido autor, uma liberdade é importante ou essencial, na medida em que ela é "um meio institucional" necessário para proteger o exercício das faculdades morais. A título de exemplo, podemos citar o "direito de ter e fazer uso exclusivo da propriedade pessoal". Por que esse é um direito essencial e como deve ser entendida sua importância? Ele é um direito

3 Em primeiro lugar, é preciso chamar a atenção para o fato de que há uma relação de prioridade do primeiro princípio, o das liberdades básicas iguais, sobre o segundo princípio, o da diferença. Além disso, em havendo conflitos no efetivo exercício das liberdades fundamentais, também é preciso estabelecer prioridades. O critério adotado por Rawls, na opinião de Hart, não é satisfatório. 
fundamental, porque proporciona "uma base material suficiente para a independência da pessoa e um sentimento de respeito" (idem, p. 160). Sem isso não se desenvolvem o senso de justiça e a concepção do bem. Por isso todas as pessoas têm esse direito. Mas ele não inclui, por exemplo, "a propriedade dos recursos naturais" e dos "meios de produção", pois isso não é necessário para o desenvolvimento e exercício das faculdades morais citadas.

É oportuno enfatizar que os referidos ajustes e regulamentações das liberdades fundamentais, tendo em vista a solução de conflitos, têm um objetivo bem claro: visam o "desenvolvimento adequado e pleno exercício das faculdades morais" dos cidadãos, isto é, a capacidade de ter senso de justiça e a capacidade de ter uma concepção do bem. O desenvolvimento dessas faculdades gera estabilidade de uma sociedade e, por conseguinte, a auto-sustentação das instituições políticas e sociais.

\section{A obediência às leis e à Constituição}

A partir da discussão em torno da necessidade da existência de princípios ético-políticos e de sua especificação na forma de liberdades básicas e de sua aplicação à Constituição de um Estado democrático, abre-se um outro debate em torno da sua aplicação no "estágio legislativo", que se segue ao "estágio constitucional”, isto é, coloca-se o problema da injustiça das leis e da sua obediência. ${ }^{4}$ Se os direitos e liberdades fundamentais devem ser garantidos pela Constituição, através da legislação pertinente, o que deve ou pode o cidadão fazer diante da edição de leis injustas? Em outras palavras: o resultado do processo político constitucional é a legislação elaborada. O critério da maioria é o recurso procedimental adotado. Levando em conta que maiorias podem errar, como proceder diante de leis injustas?

Não há dificuldades em admitir que devemos obedecer a leis justas. A convivência harmônica e os pactos sociais requerem isso de cada cidadão. Este tem consciência de que os benefícios dessa obediência lhe asseguram a realização dos direitos fundamentais e das liberdades básicas. Foi para isso que foi criado o Estado e toda a organização social. O problema está em saber em que medida temos o dever de obedecer a leis injustas. J. Rawls, em seu livro Uma Teoria da Justiça, coloca bem o problema: "A verdadeira questão está em saber em que circunstâncias e em que medida somos obrigados a obedecer a ordenações injustas" (p. 389). Percebe-se claramente a necessidade do estabelecimento de um critério para a qualificação da justiça das leis.

No que se refere à obediência à Constituição, o autor americano parte de um pressuposto básico: temos um dever natural de obedecer a uma Constituição justa e de apoiar instituições justas (cf. T. J. p. 392). Esse é um pressuposto básico de toda a sua teoria da justiça.

4 Na aplicação dos princípios de justiça, Rawls prevê a seqüência de quatro estágios: o estágio da posição original, em que se dá a adoção dos princípios; o estágio constitucional, que trata da elaboração da constituição; o estágio legislativo, que trata da elaboração das leis e políticas, e o estágio judicial, que se ocupa da aplicação das regras aos casos particulares. 
Diante disso, algumas questões se impõem: O que é uma Constituição justa? Em que princípios ela se apóia? O que são leis justas?

Há um consenso sobre o fato de que uma Constituição justa deve apoiar-se em princípios de justiça. Mas quais? Como formulá-los e fundamentá-los? Diferentes respostas são dadas. Kant, em sua Doutrina do Direito, ao referir-se à divisão dos deveres do Direito, retoma os três princípios de Ulpiano que, segundo Höffe, são os princípios mais famosos do Direito ocidental, os "princípios categóricos do Direito" (O que é justiça?, p. 57). São eles: viver honestamente (ser um homem honrado); não prejudicar ninguém; dar a cada um o que é seu, que deve ser entendido no sentido de assegurar a cada um o que é seu, ou mais precisamente, "que os direitos que já se têm sejam assegurados" (p. 60).

Recorrendo aos textos de Rawls, podemos ler: "A Constituição justa se define como uma Constituição que seria consensualmente aceita numa convenção constituinte pelos representantes racionais orientados pelos dois princípios da justiça” (T. J., p. 396).

Fica claro que uma Constituição justa se apóia ou é orientada por princípios de justiça que, para o referido autor, são dois: o princípio da igualdade e o princípio da diferença, apresentados através de várias formulações.

Quanto à legislação justa, acrescenta o autor: "leis e políticas justas são aquelas que seriam estabelecidas no estágio legislativo por legisladores racionais, que respeitam as restrições impostas por uma Constituição justa e conscientemente se esforçam para seguir os princípios da justiça, os quais tomam como um padrão" (p. 396). Nessas definições de Constituição justa e legislação justa, estão presentes três dos quatro estágios da aplicação dos princípios da justiça: o da posição original, o estágio constitucional e o estágio legislativo (cf. T. J., p. 211).

A referência explícita aos princípios da justiça evidencia a sua função reguladora e orientadora. Quaisquer leis fundamentam-se em princípios. ${ }^{5}$ A necessidade de sua obediência, portanto, enquanto justas, não causa dificuldades.

Se a Constituição justa, para o autor americano, é um "procedimento justo" que visa um "resultado justo", entendendo por procedimento "o processo político regido pela Constituição" e o resultado como sendo a "legislação elaborada", não há garantias de que leis injustas não possam ser estabelecidas. Ora, se de procedimentos políticos podem originar-se resultados injustos, como devemos comportar-nos diante deles? Mais especificamente, leis injustas devem ou não devem ser obedecidas? Como deve um governo tratar os que desobedecem às leis por motivos de consciência? E quando a validade da lei for duvidosa, o que deve o cidadão fazer?

5 A propósito, vale registrar que Dworkin, ao criticar o poder discricionário do juiz (Judicional discretion), defendido pelos positivistas (Hart é um deles), insiste na distinção entre regras, princípios e políticas e sustenta que, em não havendo regra clara disponível, é aos princípios que os juízes devem recorrer, sobretudo nos casos difíceis (cf. Levando os direitos a sério, cap. 2). 
Muitas controvérsias envolvem os temas do dever de obedecer a leis injustas e o da desobediência civil, como de resto todo e qualquer tipo de direito à resistência. Defini-los claramente é um dos primeiros aspectos da divergência. Distinguir desobediência civil da objeção de consciência é uma das dificuldades. Rawls desenvolve o problema, tendo em vista a existência de uma "sociedade quase-justa", uma "sociedade bem-ordenada", isto é, uma sociedade na qual existe uma concepção de justiça publicamente reconhecida (que inclui direitos e liberdades fundamentais) e suas instituições básicas satisfazem os princípios que constituem essa concepção. A desobediência civil só se aplica no "Estado democrático de Direito". O. Höffe acrescenta que o direito de resistência, embora prefira falar em desobediência civil, no Estado democrático de Direito, só pode ser justificado em casos especiais.

Ambos (Rawls e Höffe) concordam que mesmo os Estados democráticos não estão imunes às injustiças. Admitem que num Estado ditatorial ou num governo corrupto e injusto, não só cabe a desobediência civil, mas outras formas de resistência, inclusive o uso da força, podem ser desenvolvidas. R. Dworkin discute a desobediência civil em sentido mais amplo, incluindo toda e qualquer desobediência a uma lei, por motivos de consciência ou "razões morais" (cf. Levando os Direitos a Sério, cap. 07 e 08).

\section{A obediência a leis injustas}

Que deveres e obrigações temos para com as leis?

Numa primeira tentativa de responder à questão, podemos tomar como ponto de partida, conforme já mencionado, um pressuposto básico de J. Rawls: como cidadãos, temos o "dever natural de apoiar e promover instituições justas" (T. J., p. 370). Este é, aliás, o dever natural mais importante. Na "posição original" (situação hipotética na qual as partes não conhecem seus interesses particulares e visam a formação de um consenso em torno dos princípios da justiça), as partes concordarão com o fato de que é preciso apoiar a justiça. ${ }^{6}$ Ora, a instituição mais importante, como se pode ver já no início de Uma Teoria da Justiça, é a "Constituição Política". Quando posso dizer que é justa? Quando apoiada nos princípios da justiça (cf. p. 08). Se uma Constituição assegurar o princípio da igualdade e os direitos fundamentais; se garantir a liberdade de expressão e de imprensa; se assegurar a igualdade de oportunidades a todos, enfim, se ela garantir as liberdades básicas (principalmente as políticas), ela será justa. ${ }^{7}$ Ocorre que da Constituição poderão resultar ordenações injustas. Ou seja, o resultado do processo político regido pela Constituição, que é a legislação elaborada, pode ser injusto. Todo Estado democrático, na aplicação dos princípios da justiça, sobretudo no sistema legislativo, está sujeito a cometer injusti-

6 O tema da posição original é amplamente desenvolvido em Uma teoria da justiça (cap. 03) e $O$ Liberalismo Político (conferência 1). É ainda mais explicitado e ligeiramente reformulado em Justiça como eqüidade: uma reformulação $\$ 6$.

7 A propósito do assunto, ver J. Rawls, em Justiça como eqüidade: uma reformulação § 13, sobretudo quando trata da aplicação dos princípios da justiça à Constituição. 
ças. Ora, não há dificuldade em entender e admitir a obediência a leis justas. Mas as injustas? O grande problema "está em saber em que circunstâncias somos obrigados a obedecer a ordenações injustas?" (T. J., p. 389). E as leis cuja validade é duvidosa? Dworkin diz que, nos Estados Unidos, "quase todas as leis a que um número significativo de pessoas seria tentado a desobedecer por razões morais são também duvidosas - quando não claramente inválidas - por razões constitucionais" (Levando os direitos a sério, p. 318). Além da estreita vinculação estabelecida entre questões morais e questões jurídicas, percebe-se a força das primeiras sobre as segundas.

Ao tratar da justiça política (a justiça da Constituição), Rawls define a Constituição como um "procedimento justo" ou como "um caso de justiça procedimental imperfeita" (T. J., p. 241). Por que imperfeita? Porque as leis estabelecidas a partir dela (da Constituição), como foi dito, podem ser injustas. Ou seja, o resultado pode ser injusto. O que se quer é um sistema de legislação justo e eficaz. No entanto, a "justiça procedimental perfeita", em assuntos políticos, não é possível. ${ }^{8}$ O problema todo está na "regra da maioria", uma vez que o "processo constitucional" depende de alguma forma de votação. Ocorre que maiorias podem errar. Mas, como necessidade prática, a regra da maioria é um recurso procedimental (democrático) indispensável para a tomada de decisão. Ora, sendo o procedimento correto e considerando nosso dever natural de apoiar instituições justas, somos obrigados a obedecer a leis, por vezes, injustas. Nas palavras de Rawls: "tendo que apoiar uma Constituição justa, devemos respeitar um de seus princípios essenciais, o da regra da maioria" (T. J., p. 393). Supondo um estado de quase-justiça e considerando nosso dever de apoiar uma Constituição justa, temos o dever de obedecer a leis injustas, desde que, é claro, não ultrapassem certos limites de injustiça. No mesmo contexto certamente se enquadram as leis cuja validade é duvidosa.

\section{A regra da maioria}

Trata-se de um "recurso procedimental", uma necessidade prática. Mas, se maiorias erram ou podem errar, não haverá outro recurso melhor? Segundo Rawls, a "regra da maioria é o melhor recurso disponível para garantir uma legislação justa e eficaz". Além de ser compatível com a liberdade igual, fica claro que as decisões das maiorias (ou o princípio da maioria) também estão sujeitas aos princípios da justiça, isto é, devem levar em conta as liberdades políticas (de expressão e de reunião), a liberdade de participação e influência, etc. Mesmo assim, não está assegurado que o que as maiorias decidem é certo e justo. O resultado das votações sempre "está sujeito a princípios políticos", ou até mesmo a posições parciais e interesseiras. É claro que a discussão de um maior número de pessoas tem mais probabilidade de vir a ser correta. O debate e a argumentação abrem novas perspectivas e ampliam a visão dos participantes. Decisões tomadas por um grupo de especialistas têm maiores chances de virem a ser corretas. Ora, os legisladores deveriam ser esses especialistas nas coisas públicas e ou assuntos políticos.

8 Sobre justiça procedimental imperfeita e justiça procedimental perfeita, ver T. J. § 14 


\section{A desobediência civil}

É oportuno salientar que a desobediência civil só tem lugar no âmbito de um Estado democrático de Direito. Rawls a concebe apenas para o caso de uma sociedade bem-ordenada, isto é, naquela em que existe uma concepção pública de justiça, onde os indivíduos aceitam os mesmos princípios de justiça e as instituições sociais satisfazem esses princípios ${ }^{9}$. O autor não vê dificuldades para a desobediência civil em sistemas de governo não estabelecidos de forma legítima. Aliás, outras formas de resistência, além da desobediência civil, estão justificadas contra um sistema corrupto e injusto. A desobediência civil só se apresenta "para aqueles cidadãos que reconhecem e aceitam a legitimidade da Constituição", dentro do Estado democrático (T. J., p. 403). Rawls fala em "teoria constitucional da desobediência civil" (T. J., p. 403).

Mas o que é desobediência civil? Em que medida cessa o dever de obedecer às leis estabelecidas pelo Legislativo, tendo em vista o "direito de defender as liberdades pessoais e o dever de se opor à injustiça?" Em que circunstâncias as leis injustas podem ser desobedecidas? Dworkin e Rawls respondem diferentemente a essas questões, sobretudo no que se refere aos motivos da desobediência.

Em Uma Teoria da Justiça, o autor americano define a desobediência civil como "ato público, não-violento, consciente e não obstante um ato político, contrário à lei, geralmente praticado com o objetivo de promover uma mudança na lei e nas políticas do governo" (p. 404). É um ato público, porque é feito em público, não é secreto, mas comunicado francamente. É nesse sentido que também não é violento, principalmente por não usar a violência e a força contra as pessoas e ser "expressão conclusiva do argumento de alguém". É não-violento também, porque "expressa uma desobediência à lei dentro dos limites da fidelidade à lei [...]. A lei é violada, mas a fidelidade à lei é expressa pela natureza pública e não-violenta do ato, pela disposição de aceitar as conseqüências jurídicas da própria conduta" (p. 406). É um ato contrário à lei, uma vez que os envolvidos se opõem à lei, mesmo que ela seja mantida. É um ato político, porque se "orienta e justifica por princípios políticos, isto é, pelos princípios da justiça que regulam a Constituição e as instituições sociais em geral" (p. 406). O desobediente civil não pode apelar aos seus princípios da moral pessoal ou convicções religiosas, para justificar a desobediência. Por isso é que se pode falar em "teoria constitucional da desobediência civil". Num Estado democrático de Direito pressupõe-se a existência de uma concepção política e pública de justiça que, no caso de uma desobediência civil, é invocado. Os cidadãos tomam como referência de suas atividades e atitudes políticas os princípios da justiça vigentes na Constituição. Leis é que são tidas como injustas, mas não a Constituição. É preciso ter presente, mais uma vez, a regra da maioria, como recurso procedimental. Nesse sentido, a desobediência civil não pode ser confundida com a ação arma-

9 A noção de "Sociedade bem-ordenada" é assunto em várias obras de Rawls. Talvez a melhor explicitação possa ser encontrada em Justiça como eqüidade: uma reformulação, § 3 e em O Liberalismo Político, p. 78. Em ambos os textos, o autor reconhece que em Uma teoria da justiça a noção é pouco realista. 
da através do uso da força. Nesta não são aceitos os próprios princípios da justiça ou a concepção de justiça vigente no sistema político e não se está disposto a aceitar as conseqüências jurídicas da violação da lei; portanto, se dá fora dos limites da fidelidade à lei.

Márcio Tulio Viana, em seu livro Direito de Resistência, salienta que a desobediência civil requer um certo consenso. Pelo menos um número significativo de pessoas deve estar convencido de que "as vias normais de mudança da lei já não funcionam" (p. 56). Lembra que a desobediência civil tem em vista a reforma da lei. Por isso é pública e não feita às escondidas. Daí decorre que ela é totalmente distinta da "desobediência criminosa". Nesta não se age às claras; não se tem em vista a mudança da lei, mas a fuga dela; o que importa é o interesse pessoal e não a procura da justiça (cf. 58).

Dworkin sustenta poder o cidadão alegar "razões morais", para justificar a desobediência civil. Considera-a, portanto, em sentido mais amplo do que a conceituação de Rawls.

Em linhas gerais, O. Höffe concorda com a concepção de desobediência civil de J. Rawls. Em O que é justiça?, o filósofo alemão entende que nos Estados democráticos de Direito, a única desobediência legítima deve dar-se dentro dos seguintes aspectos: é de "ordem moral-política"; “ocorre em público"; é não-violenta; é ato contrário à lei, com o intuito de mudá-la; "as formas legais do protesto e da oposição já devem ter sido exauridas" (é o que Rawls coloca como uma das condições para a desobediência civil); os desobedientes devem estar dispostos a aceitar as conseqüências da desobediência (p. 135).

\section{Condições para a prática da desobediência civil}

Em que circunstâncias justifica-se a desobediência civil? Os argumentos apresentados por J. Rawls, sobretudo no que se refere aos seus princípios de justiça, são sugestivos:

$1^{\underline{0}}$ - A desobediência civil está plenamente justificada, sempre que houver "sérias infrações do primeiro princípio da justiça, o princípio da liberdade igual, e gritantes violações da segunda parte do segundo princípio, o princípio da igualdade eqüitativa de oportunidades" (T. J., p. 412). Assim, negar a determinadas minorias o direito de votar, o direito de ocupar cargos públicos, o direito de propriedade, o direito de ir e vir, a liberdade de expressão e de imprensa, são exemplos de violação dos princípios de justiça e, portanto, justifica-se a desobediência.

$2^{\underline{0}}$ - Quando fracassarem todas as tentativas de provocar a revogação de leis injustas, a desobediência civil passa a ser o último recurso. Os meios legais disponíveis foram examinados e usados, e não se obtendo qualquer sucesso, a desobediência passa a ser a única alternativa. Para Rawls, é preciso ter certeza de que não há mais outro recurso disponível, a não ser a desobediência civil. Estamos falando de um Estado democrático de Direito. Portanto, não podemos queimar etapas. É claro que o autor americano reconhece que existem situações "tão radicais" em que os meios legais de oposição política podem ser dispensados. 
$3^{\circ}$ - Quando várias minorias têm justificativas para recorrer à desobediência civil, torna-se necessário um "acordo de cooperação política" entre elas, para evitar um "colapso em relação à lei e à Constituição". Não é possível que todos os que sofrem injustiças recorram ao mesmo tempo à desobediência civil. Embora de difícil execução, um "entendimento político" entre essas minorias torna-se necessário. Às vezes, o rodízio pode ser uma solução para equacionar as reivindicações.

Observe-se que, na perspectiva de Rawls, "razões morais" não são aceitas para justificar a desobediência civil.

\section{7 papel da desobediência civil}

Foi referido que estamos tratando de "uma teoria constitucional da desobediência civil". Qual é o seu papel dentro de um sistema constitucional e como se vincula ao governo democrático? Pressupõe-se que, mais uma vez, estamos tratando de uma sociedade bem-ordenada, uma sociedade vista como um "sistema de cooperação entre pessoas iguais". Havendo, portanto, uma concepção política e pública de justiça, não se pode admitir que alguns sofram graves injustiças. Nesse caso, como foi dito, a desobediência está justificada. Ora, percebe-se claramente o quanto é importante que exista a possibilidade de desobediência. Ou seja, usando a expressão de Rawls, a desobediência civil "é um dos recursos estabilizadores de um sistema constitucional" (T. J., p. 424). O fato de existir a possibilidade da não-obediência faz com que se mantenha toda a cautela na elaboração das leis e políticas, levando-se em conta os princípios da justiça. A desobediência civil, na dicção do autor, "ajuda a manter e a reforçar as instituições justas; [...] serve para prevenir desvios da rota da justiça e corrigi-las quando acontecem"; traz estabilidade para uma sociedade bem-ordenada (T. J., p. 425). Embora contrária à lei, a desobediência civil, visando a defesa dos princípios da justiça, é moralmente correta, pois pretende manter o regime constitucional, ou seja, "visa manter a estabilidade de uma constituição justa". Daí a tese de Rawls: "a teoria constitucional da desobediência civil repousa unicamente sobre uma concepção da Justiça" (T. J., p. 426). Por isso a insistência em referir-se sempre a uma sociedade bem-ordenada ou quase-justa, ao falar da desobediência civil. Esta sociedade pressupõe uma concepção de justiça publicamente reconhecida. Não existe uma sociedade estável, sem uma concepção pública de justiça e, saliente-se, em especial, sem o senso de justiça, por parte dos cidadãos (cf. T. J., p. 433). Dentro desse contexto, uma "certa desobediência civil" deve ser tolerada. Dworkin é dessa posição, sobretudo quando está em jogo a posição moral de seus praticantes. Afirma o autor: "Não conheço nenhuma prova genuína de que a tolerância de uma certa desobediência civil, por respeito à posição moral de seus praticantes, contribua para aumentar essa desobediência, e muito menos o crime em geral (Levando os direitos a sério, p. 301).

Em resumo: partimos de princípios ético-políticos enquanto reguladores e orientadores das instituições jurídicas e sociais. Eles enunciam os direitos e liberdades básicos como iguais. O objetivo é que os princípios sejam aplicados à Constituição e 
garantidos por ela. Na aplicação do sistema legislativo entra o critério da maioria enquanto recurso procedimental. Ora, como maiorias podem errar, existe a possibilidade da edição de leis injustas. Se, por um lado, é nosso dever obedecê-las, tendo em vista que os procedimentos adotados foram corretos (justiça procedimental), e considerando nosso dever fundamental de apoiar instituições justas, por outro, justifica-se a desobediência, levando em conta que estamos num Estado democrático de Direito e que os direitos e liberdades fundamentais não foram respeitados. A desobediência civil pressupõe o reconhecimento de uma concepção política de justiça e tem, assim, uma função estabilizadora do regime constitucional.

\section{Desobediência civil e objeção de consciência}

J. Rawls faz uma distinção entre desobediência civil e objeção de consciência, atribuindo à primeira um sentido mais restrito. Reconhece que habitualmente essa separação não é feita, entendendo-se a primeira como sendo qualquer desobediência à lei por "razões de consciência" ou "razões morais". É o que faz R. Dworkin em Levando os direitos a sério (cf. cap. 08). Ele estabelece uma ligação próxima entre questões morais e questões jurídicas. "De que forma o governo deveria proceder com aqueles que desobedecem, por razões de consciência, às leis referentes ao recrutamento militar?" pergunta o autor. Ou ainda: pode a desobediência às leis estar moralmente justificada ou pode-se apenas justificá-la juridicamente?

Para Dworkin, os motivos que levam ou justificam a desobediência civil podem ser os da objeção de consciência ou "objeções morais". Rawls não admite tal justificação para a desobediência civil, definindo-a, portanto, em sentido mais restrito. A objeção de consciência, para ele, não tem as características da desobediência civil. Ela não apela ao "senso de justiça da maioria", por não invocar as convicções de uma comunidade. Ela é uma desobediência ou uma "recusa" a uma ordem legal ou administrativa, por "razões de consciência". Nesse sentido, não é praticada publicamente. Os que a praticam não têm muita esperança em mudar as leis ou políticas, como é o caso da desobediência civil. Via de regra, a objeção de consciência não se baseia em princípios políticos ou numa concepção política de justiça. Podem ser motivos religiosos, ou pode haver outros fundamentos. A desobediência civil, por sua vez, compartilha de uma concepção pública de justiça, portanto, conhecida pela comunidade. É claro que a objeção de consciência também pode basear-se em motivos políticos. Exemplo típico é o caso do soldado que se nega a cumprir uma ordem, por considerar injustos os motivos de uma guerra. O problema é saber se poderá haver punição por parte do Estado, tendo em vista essa desobediência. Rawls reconhece que, em muitas situações concretas, há dificuldades em distinguir desobediência civil e objeção de consciência.

Para Dworkin, o problema da obediência ou desobediência às leis não se coloca somente no que diz respeito à justiça ou injustiça das leis. A questão central referese ao fato de a validade da lei poder ser duvidosa. Para que ela seja objeto de dúvida, segundo o autor, basta que um número significativo de pessoas fique tentado a desobedecer por "razões morais". "A Constituição torna nossa moral política convencional relevante para a questão da validade" (Levando os direitos a sério, p. 318). 
Pelo que se pode observar, o referido autor não faz uma separação entre desobediência civil e objeção de consciência e dá exemplos para mostrar como as "razões de consciência" colocam em dúvida a validade de muitas leis. Refere-se ao caso do recrutamento nos Estados Unidos (por ocasião da guerra do Vietnã), mostrando que o desacordo e os protestos baseavam-se em "objeções morais", como, por exemplo, o fato de os Estados Unidos estarem usando armas e táticas imorais no Vietnã; que a guerra não teve o respaldo dos representantes do povo; que, ao isentar os estudantes universitários da apresentação e prestação de serviço militar ou de adiar sua apresentação, descriminaram-se os que não são favorecidos economicamente, o que é imoral. Pode-se perceber que, nesse caso, a desobediência civil tem um sentido mais amplo, incluindo a objeção de consciência. Segundo o autor, para os juristas, esses argumentos morais fornecem a base para os argumentos constitucionais. A necessidade de que o Congresso declare a guerra como uma das determinações constitucionais é um exemplo disso. Que não pode haver discriminação em favor dos estudantes universitários, isentando-os do recrutamento, decorre da determinação constitucional da igual proteção da lei para todos. Esse é outro exemplo.

Dará a Constituição Brasileira margem à desobediência civil ou à objeção de consciência, considerando tratar-se de um Estado democrático de Direito?

Ao distinguir a desobediência civil da objeção de consciência, Márcio Viana cita o artigo 5을 Inciso VIII, onde se lê: "ninguém será privado de direitos por motivo de crença religiosa ou de convicção filosófica ou política, salvo se as invocar para eximir-se de obrigação legal a todos imposta e recusar-se a cumprir prestação alternativa, fixada em lei" e endossa o comentário de Afonso da Silva, segundo o qual, no referido dispositivo, é reconhecido o direito de escusa, "mas a lei pode impor ao recusante prestação alternativa, que, por certo, há de ser compatível com suas convicções" (Direito de Resistência, p. 59). É importante perceber que existe a possibilidade da pena alternativa que pode, por sua vez, levar em conta as convicções morais do cidadão recusante. Pode-se, portanto, falar em direito à objeção de consciência, de acordo com o referido dispositivo. Também em desobediência civil, segundo Dworkin.

\section{Objeção de consciência e Direito Internacional}

O problema que aqui se coloca é o da aplicação da "teoria do dever político à política externa”. Se a justificativa da desobediência civil refere-se aos assuntos internos, a justificativa da objeção de consciência diz respeito à política externa. Nesta última, a teoria da justiça é estendida ao Direito Internacional. O objeto de análise de Rawls, para justificar a objeção de consciência, são "certos atos de guerra" e o serviço militar. O autor amplia a interpretação da posição original para pensar nos representantes de diferentes nações que agora devem escolher princípios para julgar conflitos entre os Estados. Se antes falávamos em princípios (por exemplo, o princípio da eqüidade) para os indivíduos e instituições, agora falamos em princípios para os Estados. O que se pretende, através da posição original, é 
estabelecer uma situação de eqüidade entre as nações e anular "as contingências e tendências do rumo histórico" (cf. T. J., p. 419). O autor fala em "segunda posição original", agora para estender uma concepção liberal ao "Direito dos Povos" (cf. Direitos dos Povos, p. 41). A justiça internacional se constitui dos princípios escolhidos nessa posição original.

Que princípios seriam esses? Segundo o autor em discussão, "o princípio básico do Direito Internacional é o princípio de igualdade" (p. 419). Povos organizados como Estados têm certos princípios básicos iguais. Dessa igualdade das nações resulta o "princípio da autodeterminação" dos povos; o "direito da autodefesa"; o dever de cumprir tratados internacionais. É a partir desses princípios que é definida uma causa justa para uma guerra, por parte de uma nação.

A propósito disso, Rawls e Dworkin discutem o problema da obrigação ou do dever de servir às forças armadas, numa determinada guerra. É o problema do recrutamento para uma possível guerra injusta. Para resolver a questão, precisamos examinar o "objetivo" de uma guerra e a "forma" como é conduzida. Cumprir o dever de entrar para o serviço militar depende da resposta a esses dois aspectos. Se o objetivo for a preservação das instituições justas, numa determinada sociedade, justifica-se o recrutamento. Sendo este uma interferência nas liberdades individuais, só pode ser admitido em vista da defesa da própria liberdade e da dos outros cidadãos.

Isso significa que qualquer cidadão (de uma sociedade bem-ordenada) pode recusar-se a entrar nas forças armadas, alegando "razões de consciência", isto é, sustentando que os motivos da guerra são injustos. Exemplo: vantagens econômicas ou o aumento do poder nacional não são motivos que justificam a interferência na liberdade dos cidadãos, como é o caso do recrutamento. Rawls chama a atenção, no entanto, que às vezes não é o objetivo da guerra que motiva a recusa do dever de obedecer, mas a maneira como o conflito é conduzido. A exposição ou exibição de presos políticos, nos meios de comunicação, pode ser tomada como exemplo. Rawls fala em "violação da lei moral da guerra" (cf. T. J., p. 422).

\section{O senso de justiça}

Não se pode discutir o problema da desobediência civil sem uma referência ao tema do "senso de justiça" e de como este é adquirido e desenvolvido. Somente aos cidadãos, que conhecem uma concepção pública de justiça, e são capazes de desenvolvê-la, pode-se permitir que lancem mão da desobediência civil.

Temos que voltar a um pressuposto de toda Teoria da Justiça de J. Rawls: a noção de "pessoa ética". O autor, em Uma Teoria da Justiça, mostra que as partes, na "posição original", são iguais. Isso se refere a certas condições como, por exemplo, que todas as pessoas têm os mesmos direitos na escolha dos princípios; que podem fazer propostas e apresentar razões, etc. Com isso pretende mostrar que a igualdade refere-se aos "seres humanos como pessoas éticas". Na mesma obra, diz que "pessoas éticas" são aquelas que têm uma "concepção de bem" e que são capazes de ter "um senso de justiça" (p. 21). Em O Liberalismo 
Político, reitera essa pressuposição, explicitando mais claramente em que consistem essas duas capacidades, até porque se refere a uma concepção política de pessoa. Senão vejamos: "Senso de justiça é a capacidade de entender a concepção pública de justiça que caracteriza os termos eqüitativos da cooperação social, de aplicá-la e de agir de acordo com ela" [...]. "A capacidade de ter uma concepção do bem é a capacidade de formar, revisar e procurar concretizar racionalmente uma concepção de vantagem racional pessoal, ou bem" ( p. 62).

Ora, se são capacidades, precisam ser desenvolvidas, como, aliás, escreve Descartes: "Não basta ter espírito bom, o essencial é aplicá-lo bem" (Discurso do Método, livro 199). A compreensão e a aplicação dos princípios da justiça pressupõem pessoas éticas, portanto, pessoas capazes de adquirir um senso de justiça e ter uma concepção do bem. No capítulo VIII de Uma Teoria da Justiça, depois de ter explicado a concepção do bem, Rawls discute o que chama de "aquisição do senso de justiça pelos membros de uma sociedade bem-ordenada" (p. 503).

Ora, a desobediência civil, como "recurso estabilizador" de um sistema constitucional, requer senso de justiça. Portanto, só pode ser instaurada por pessoas éticas. É por isso que na parte que trata dos objetivos, o autor americano volta a falar de estabilidade e auto-sustentação de sua teoria. Refere-se, novamente, à sociedade bem-ordenada, evidenciando que nela todos aceitam e sabem que os outros aceitam os mesmos princípios da justiça. A sociedade, na qual existe uma concepção pública de justiça, há que perdurar ao longo do tempo, pois a concepção de justiça aí vigente é estável. Quem dá a estabilidade é o senso de justiça dos cidadãos. Ora, instituições justas, as organizações, por exemplo, fazem com que os indivíduos que delas participam adquiram e cultivem o senso de justiça. Quem vive em organizações justas, aprenderá a ser justo. O senso de justiça cultivado cria e fortalece a estabilidade dessas instituições. Nesse caso, sustenta Rawls, o senso de justiça será "mais forte do que as propensões para a injustiça" (T. J., p. 505). Em outra passagem, podemos ler: "a natureza humana é tal que adquirimos um desejo de agir de forma justa, quando vivemos em instituições justas e nos beneficiamos delas" (T. J., p. 506). Isso produz estabilidade. O autor considera que a sua teoria, a da justiça como eqüidade, é mais estável do que as outras alternativas. Isso porque ela gera a sua própria sustentação. Assim, a desobediência civil, exercida por pessoas éticas, isto é, por pessoas que têm senso de justiça, produzirá estabilidade.

Se o senso da justiça é tão importante na geração da estabilidade, precisamos mostrar como se dá a "aquisição do entendimento dos princípios da justiça". Rawls fala em "desenvolvimento moral". Refere-se a três momentos ou estágios desse desenvolvimento: a moralidade de autoridade, a do grupo, e a dos princípios (T. J., p. 512).

A moralidade de autoridade é a primeira etapa do desenvolvimento moral. Inicia-se com a moralidade da criança e desenvolve-se gradualmente na medida em que ela vai crescendo. Isso significa que o senso de justiça não é inato e sim adquirido. As atitudes morais precisam ser ensinadas às crianças, e isso começa na família. A criança, vendo-se amada pelos pais, aprenderá a admirá-los e respeitá- 
los e sujeitar-se-á à sua autoridade. Os pais, por sua vez, "devem enunciar regras inteligíveis e claras (e, sem dúvida, justificáveis), adaptadas ao nível de compreensão da criança". [...] "Devem exemplificar a moralidade que impõem" (T. J., p. 516). É importante que a criança perceba gradualmente que a autoridade dos pais deve ser respeitada, não em vista de recompensas ou punições, mas em vista de uma conduta que vai no sentido oposto aos das inclinações naturais.

A moralidade do grupo é mais ampla. Seu conteúdo "é ditado pelos padrões morais adequados ao papel do indivíduo nas várias associações às quais pertence" (T. J., p. 518). O senso comum é quem dita as regras de moralidade. O sistema da cooperação faz com que consideremos os diferentes pontos de vista, necessidades e objetivos e planos de vida. A convivência com as diferenças leva os indivíduos a regular sua conduta de acordo com elas. Virtudes voltadas para a cooperação caracterizam a moralidade do grupo: "a da justiça e eqüidade, a da fidelidade e confiança, a da integridade e imparcialidade” (T. J., p. 524).

A moralidade dos princípios é a moralidade de uma pessoa justa. Ao atingir a moralidade do grupo, o cidadão já adquire um "entendimento dos princípios da justiça”. Isso conduz ao "conhecimento dos padrões de justiça” (cf. T. J., p. 525).

Nesses três estágios do desenvolvimento moral, pode-se observar um processo de universalização de máximas na direção de princípios. E isso é um aprendizado. A criança precisa, desde os primeiros anos de vida, ser educada para respeitar certas regras de conduta, a fim de que tenhamos um cidadão ciente dos princípios de justiça, portanto, com senso de justiça. Este não é inato, precisa ser adquirido. Poder-se-ia dizer que a capacidade é inata, mas precisa ser desenvolvida. Vale a analogia com a lição de J. Locke: a capacidade de conhecer é inata, mas o conhecimento é adquirido (cf. Ensaio acerca do entendimento humano, p. 146). À pergunta sobre a melhor maneira de educar eticamente um filho, Hegel endossa a resposta de um pitagórico: "fazendo-o cidadão de um Estado com boas leis" (Filosofia do Direito § 153).

Rawls indica duas maneiras de manifestação do senso de justiça. A 1a "nos leva a aceitar as instituições justas que se aplicam a nós e das quais nós e nossos consócios nos beneficiamos”. O que liga os cidadãos entre si não são apenas laços de companheirismo, mas a "aceitação de princípios públicos de justiça". 2ª "um senso de justiça fomenta uma disposição de trabalhar em favor (ou pelo menos de não trabalhar contra) a construção de instituições justas e no sentido de reformar as instituições existentes, quando a justiça o exija” (T. J., p. 526). Contrariar o senso de justiça provoca um sentimento de culpa em relação aos princípios de justiça. Na criança não ocorre esse sentimento de culpa, porque não há ainda a compreensão do ideal moral. Na moralidade de grupo, esses sentimentos estão ainda vinculados aos laços de amizade que temos para com indivíduos em determinadas comunidades. No que se refere à "moralidade de princípios", uma vez aceita esta, "as atitudes morais deixam de estar unicamente ligadas ao bem-estar e à aprovação de indivíduos ou grupos específicos, e são moldadas por uma concepção do justo escolhida independentemente dessas contingências" (T. J., p. 527). 
A propósito, uma importante questão é formulada pelo autor em discussão: "Como é possível que princípios de justiça conquistem nossa afeição?" (T. J., p. 528). Em outras palavras: como é possível que venhamos a ter o desejo de agir de acordo com a justiça?

Dois aspectos merecem realce, na análise do autor americano:

$1^{\underline{0}}$ - Os princípios de justiça, na posição original, são escolhidos por pessoas racionais que, enquanto tais, procuram promover os interesses já aceitos pelas pessoas. Princípios inúteis serão, obviamente, rejeitados. Os princípios da justiça são objeto de um acordo; são selecionados a partir de um conjunto de concepções de justiça já conhecido e existente na tradição da filosofia política. São conquistas da história. Basta examinar os regimes democráticos e haveremos de verificar direitos e liberdades básicas protegidos pelos regimes mais bem-sucedidos.

$2^{\circ}$ - "O senso de justiça é um prolongamento do amor pela humanidade". Os princípios da justiça devem orientar os indivíduos que interagem entre si. O amor pela humanidade tem neles o que há de comum, na regulação de seus atos. Ao agirem de acordo com esse algo comum, que os princípios da justiça representam, os indivíduos, motivados pelo senso de justiça, serão capazes de organizar uma sociedade civilizada. Ou como expressa Rawls: "Sem senso de justiça comum ou coincidente, o civismo não pode existir" (T. J., p. 529). O desejo de agir de acordo com a justiça, portanto, resulta do claro conhecimento e consciência de princípios comuns relacionados aos objetivos racionais dos indivíduos. Somente posso desejar aquilo de que tenho pleno conhecimento. A obediência à Constituição e às leis tem isso como pressuposto.

\section{Referências}

RAWLS. J. Uma Teoria da Justiça. São Paulo: Martins Fontes, 1997. . O Liberalismo Político. São Paulo: Ática, 2000.

. Justiça como Eqüidade: uma reformulação. São Paulo: Martins Fontes, 2003.

Direito dos Povos. São Paulo: Martins Fones. 2002.

Justiça e Democracia. São Paulo: Martins Fontes, 2000.

VIANA, Márcio Tulio. Direito de Resistência. São Paulo: LTr, 1996.

HEGEL, G.W.F. Grundlinien der Philosophie des Rechts. Frankfurt am Main: Suhrkamp, 1986.

LOCKE, J. Ensaio acerca do Entendimento Humano. São Paulo: Abril Cultural, Os Pensadores, 1980.

DWORKIN, R. Levando os Direitos a Sério. São Paulo: Martins Fontes, 2002.

KANT, I. Doutrina do Direito. São Paulo: Ícone, 1993.

HÖFFE, O. O que é Justiça? Porto Alegre: EDIPUCRS, Coleção Filosofia 155, 2003.

PERELMAN, Chain. Ética e Direito. São Paulo: Martins Fontes, 2002. 